\title{
Relationship among Job Involvement, Job Enrichment, Organizational Commitment and Job Satisfaction of Nurses
}

\author{
Fatma Rushdy Mohamed \\ Assistant Professor of Nursing Administration, Faculty of Nursing, Assiut University, Egypt.
}

\begin{abstract}
Job involvement and job enrichment are the steps used to make the employees feeling that the organization is actually owning them and that thing boost their performance on the job. Aims were to study the relationship among job involvement, job enrichment, organizational commitment and job satisfaction of nurses at main Assiut University Hospital \& its' relations with nurses age and years of experience, and design a model for the association among study variables. A descriptive correlational study design was used. The study sample consisted of 203 nurses having diploma degree working in various departments of the hospital. A self-administered questionnaire was used for data collection. It included five parts as the following, nurse's personal characteristics, job involvement, job enrichment, organizational commitment, and job satisfaction questionnaires. Results: Job satisfaction had strong positive statistically significant correlations with job involvement $(\mathrm{r}=0.664)$, job enrichment $(\mathrm{r}=0.537)$ and commitment ( $\mathrm{r}=0.647)$. Job involvement, job enrichment and organizational commitment had a negative correlation with nurses' age ( $r=-0.176 ; \mathrm{r}=-0.106$; and $\mathrm{r}=-0.056)$ respectively; in-addition job enrichment and organizational commitment had a negative correlation with years of experience $(r=-0.068 ; r=-0.022)$ respectively. Conclusion Designing a model that shows a positive association among job involvement, job enrichment, organizational commitment, and job satisfaction among nurses. Recommendations: Replication of the study should be done to test the proposed model designed in the present study at different health care settings.
\end{abstract}

Key words: Job involvement, Job enrichment, Organizational commitment, Job satisfaction \& Nurses.

\section{Introduction}

There is much research and anecdotal evidence suggesting that organizational commitment leads to, or is associated with variables of great importance for organizational success and efficiency - or lack thereof - such as absenteeism, labor turnover and productivity (Robbins, 2005). It is therefore of crucial importance for managers of organizations to know what variables lead to or are antecedents of organizational commitment and lead to job satisfaction. Such knowledge would enable these managers to create conditions that are conducive to the development of such antecedents of organizational commitment and job satisfaction in their organizations (Raymond \& Mjoli, 2013).

Hackett, Lapierre, \& Hausdorf, (2001) defined job involvement as a belief about one's current job and is a function of how much the job can satisfy one's wishes. Highly job involved individuals make the job a central part of their personal character. Besides, people with high job involvement focus most of their attention on their job. Most of the researchers are agreed on this fact that job involvement is different construct from other associated constructs which includes organizational commitment, job satisfaction and intrinsic motivation.

Balay, (2000) study job involvement and grouped it into four diverse categories. These categories: 1) work as a central life interest, 2) active participation in the job, 3) performance as central to self-esteem, and 4) performance compatible with self-concept. In work as a central life interest, job involvement is thought of as the degree to which a person regards the work situation as important and as central to his/her identity because of the opportunity to satisfy main needs. In active participation in the job, high job involvement hints the opportunity to make job decisions, to make an important contribution to organizational goals, and self-determination. Active participation in the job is thought to ease the achievement of such needs as prestige, self-respect, autonomy, and self-regard. In performance as central to self-esteem, job involvement implies that performance on the job is central to his/her sense of worth.

Job enrichments are efforts to develop more positive work attitudes, for example by reinforcing motivating factors or rearranging work authorization. Job enrichment therefore is considered a vertical enrichment of work because it alters authority and responsibility, as well as level of complexity and specificity of individual assignments. It is an effort to change the content of the work so that employees are offered opportunities for success and personal development. It aims to make the job more meaningful and satisfying. With this approach there is a greater work variety, depth, and involvement 
with planning, responsibilities, and control. The goals of job enrichment on the other hand are to improve job satisfaction and avoid routine work. The goal of job enrichment is to allow workers to demonstrate their skills and abilities and improve their job satisfaction, while maximizing service and productivity (Tomey, 2000). In Turkish study organizational improvements aim to incorporate positive human and work elements. It also involves apportioning activities, tasks, and responsibilities to staff members to meet organizational goals (Can et al., 2001).

Job enrichment is the process of "improving work processes and environments so they are more satisfying for employees". Many jobs are monotonous and unrewarding - particularly in the primary and secondary production organizations. Workers can feel dissatisfied in their position due to a lack of a challenge, repetitive procedures, or an overcontrolled authority structure. Job enrichment tries to eliminate these problems, and bring better performance to the workplace. Job enrichment is a type of job redesign intended to reverse the effects of tasks that are repetitive requiring little autonomy. Some of these effects are boredom, lack of flexibility, and employee dissatisfaction. The underlying principle is to expand the scope of the job with a greater variety of tasks, vertical in nature, that require self-sufficiency. Since the goal is to give the individual exposure to tasks normally reserved for differently focused or higher positions, merely adding more of the same responsibilities related to an employee's current position are not considered job enrichment (Leach \& Wall, 2004).

Organizational commitment is considered to be one of the most important and crucial outcomes of human resource strategies. Furthermore employee commitment is seen as the key factor in achieving competitive performance (Sahnawaz \& Juyal, 2006). A significant relationship has been identified between job satisfaction and organizational commitment (Narimawati, 2007).

Samad, (2007) also tried to determine the level of influence job satisfaction facets will have on organizational commitment. Job satisfaction, on the other hand, can be defined as a pleasurable feeling that results from the perception that one's job fulfils or allows for the fulfillment of one's important job values. Job satisfaction is of great importance because it seems to affect overt organizational behavior.

Organizational commitment is the employee's identification with a particular organization and his or her desire to maintain membership in the organization. Job involvement refers to the extent to which a person is interested in and committed to his or her assigned tasks. Job satisfaction is a general attitude toward one's job or it is the difference between the amount of rewards workers receive and the amount they believe they should receive. Important aspects of job satisfaction may includepay, one's supervisors, the nature of tasks performed, an employee's co-workers or team, and the immediate working conditions. Job satisfaction also depends on the employees' level of satisfaction with their existing career and also the amount of job security they have within the organization. Where, career satisfaction is an intrinsic output of career success that refers to the satisfaction with the present jobs and advancement potential at the specific job; and job security is the employees expectation about continuity in a job situation (Can et al., 2001).

\section{Significance of the study}

Establishing a link between job involvement \& job enrichment, and \& job satisfaction on the one hand, and organizational commitment on the other, could be to the benefit of organizations as management could put in place human resources practices that increase the levels of job involvement, job enrichment and job satisfaction among employees and hence impact positively on their commitment to the organization. The results of this study will show whether job involvement, enrichment and job satisfaction have an impact on organizational commitment. It is important for organizations to implement strategies that increase job involvement and organizational commitment. So, the researcher decided to examine the relationship among job involvement, job enrichment, organizational commitment and job satisfaction of nurses at Main Assiut University Hospital.

\section{Aim of the study were to:}

- Study the relationship among job involvement, job enrichment, organizational commitment and job satisfaction of nurses at Main Assiut University Hospital.

- Study relationship among study variables (job involvement, job enrichment, organizational commitment and job satisfaction ) with age and years of experience of nurses at Main Assiut University Hospital.

- Design a model for the association among job involvement, job enrichment, organizational commitment and job satisfaction with age and years of experience of nurses at Main Assiut University Hospital. 


\section{Research questions}

- Are there associations among job involvement, job enrichment, organizational commitment and job satisfaction of nurses?

- Are nurses age and years of experience had associations with job involvement, job enrichment, organizational commitment and job satisfaction?

Methodology

Design

A descriptive correlational study design was used in the present study.

\section{Setting}

This study was carried out at Main Assiut University Hospital.

\section{Subject}

The study sample consisted of all the nursing staff having nursing secondary school (diploma) with total number of ( $n=203)$ working in inpatient departments of the hospital during the time of the study.

\section{Data collection tools}

A self-administered questionnaire was used for data collection. It included five parts.

- The first part was concerned with data about nurses' personal characteristics data. The second part was a job involvement scale which developed by Kanungo, (1982). and consisted of twenty threeitems.

- The third part consisted of sixteen items related to job enrichment scale which developed by Kanungo, (1982).

- The fourth part was for assessment of organizational commitment. It was developed by Cook and Wall (1980), and measures three domains of commitment: emotional (8 items), continuous (8 items), and natural commitment ( 7 items). The last part was a job satisfaction scale, which is a thirteen-item tool based on Michigan Organizational assessment Questionnaire (Seashore et al., 1982).

The responses in the last four parts of the tool were a five-point Likert scale: strongly agree, agree, neutral, disagree, and strongly disagree. The scoring was accordingly from 5 to 1 for each item. The scores of the items were summed-up and the total divided by the number of the items in each scale and subscale, giving a mean score. These scores were converted into a percent score. The nurse involvement, enrichment, commitment, and job satisfaction was considered high if the total percent score was $60 \%$ or higher and low if less.

The last four parts of the tool were translated in Arabic using the translate-re-translate process to ensure its validity. Their reliability was assessed in a pilot study by measuring their internal consistency using Cronbach's alpha coefficient method. This turned to be 0.970 for involvement, 0.967 for enrichment, 0.972 for commitment, 0.828 for job satisfaction, thus indicating a high degree of reliability .The validity was measured by five experts in the field of nursing administration.

\section{Pilot study}

The pilot study also served to test the feasibility of the study and the clarity and practicability of the data collection tool. It was carried out on 20 nurses from different inpatient departments at Main Assiut University Hospital. The pilot study sample was excluded from the total sample. Data collected from the pilot study were reviewed and used in making the necessary modifications prior to the finalization of the data collection tool.

\section{Fieldwork}

An official permission was obtained from the hospital director, the nursing service director, and the head of each department before embarking on the study. After the finalization of the study tool, the actual data collection was started in May 2013 and ended in June 2013. The researcher met with the eligible nurses, explained to them the purpose of the study, and asked for their oral consent to participate. Those who agreed to participate were given the tool and asked to fill it out and return it anonymously in the same setting or at most the next day. The researcher was available for any clarifications.

\section{Ethical considerations}

All the relevant principles of ethics in research were followed. The study protocol was approved by the pertinent authority. Participants' consent to participate was obtained after informing them about their rights to participate, refuse, or withdraw at any time. Total confidentiality of any obtained information was ensured. The study maneuver could not entail any harmful effects on participants.

\section{Statistical analysis}

Data entry and statistical analysis were done using SPSS 16.0 statistical software package. Data were presented using descriptive statistics. Pearson correlation analysis was used for assessment of the inter-relationships among quantitative variables, and Spearman rank correlation for ranked ones. To identify the independent predictors of job satisfaction, multiple stepwise regression analysis was used after testing for linearity, normality, homoscedasticity, and collinearity, and analysis of variance for the full regression models was done. Statistical significance was considered at p-value $<0.05$. A model proposed (Fig. 1) in this study, specifying causal links between nurses job involvement, job enrichment, job commitment to job satisfaction was tested using regression equations. 


\section{Results}

Table (1):Personal characteristics of nurses in the study sample ( $n=203)$.

\begin{tabular}{|c|c|c|}
\hline & Frequency & Percent \\
\hline \multicolumn{3}{|c|}{ Age (years) } \\
\hline $21-$ & 69 & 34.0 \\
\hline $30-$ & 59 & 29.1 \\
\hline $40-$ & 75 & 36.9 \\
\hline Range & \multicolumn{2}{|c|}{$18.0-38.0$} \\
\hline Mean \pm SD & \multicolumn{2}{|c|}{$24.75 \pm 0.96$} \\
\hline \multicolumn{3}{|c|}{ Department } \\
\hline Medical & 110 & 54.2 \\
\hline Surgical & 93 & 45.8 \\
\hline \multicolumn{3}{|l|}{ Sex } \\
\hline Male & 63 & 31.0 \\
\hline Female & 140 & 69.0 \\
\hline \multicolumn{3}{|c|}{ Experience years } \\
\hline $5-$ & 10 & 6.7 \\
\hline $10-$ & 130 & 86.7 \\
\hline $20-$ & 10 & 6.7 \\
\hline Range & \multicolumn{2}{|c|}{$1.0-20.0$} \\
\hline Mean \pm SD & \multicolumn{2}{|c|}{$10.14 \pm 1.04$} \\
\hline
\end{tabular}

Table (2): Distribution of level of agreement of job involvement, enrichment, job commitment and satisfaction among studied nurses $(n=203)$.

\begin{tabular}{|c|c|c|}
\hline & Frequency & Percent \\
\hline \multicolumn{3}{|c|}{ job Involvement } \\
\hline $\operatorname{High}(60 \%+)$ & 90 & 44.33 \\
\hline Low $(<60 \%)$ & 113 & 55.67 \\
\hline \multicolumn{3}{|c|}{ job Enrichment } \\
\hline High $(60 \%+)$ & 153 & 75.37 \\
\hline Low $(<60 \%)$ & 50 & 24.63 \\
\hline \multicolumn{3}{|l|}{ Commitment } \\
\hline \multicolumn{3}{|l|}{ Emotional: } \\
\hline High $(60 \%+)$ & 63 & 31.03 \\
\hline Low $(<60 \%)$ & 140 & 68.96 \\
\hline \multicolumn{3}{|l|}{ Continuous } \\
\hline $\operatorname{High}(60 \%+)$ & 118 & 58.13 \\
\hline Low $(<60 \%)$ & 85 & 41.87 \\
\hline \multicolumn{3}{|l|}{ Natural } \\
\hline High $(60 \%+)$ & 113 & 55.67 \\
\hline Low $(<60 \%)$ & 90 & 44.33 \\
\hline \multicolumn{3}{|c|}{ Total commitment } \\
\hline High $(60 \%+)$ & 77 & 37.94 \\
\hline Low $(<60 \%)$ & 126 & 62.06 \\
\hline \multicolumn{3}{|c|}{ Job satisfaction } \\
\hline High $(60 \%+)$ & 76 & 37.44 \\
\hline Low $(<60 \%)$ & 127 & 62.56 \\
\hline
\end{tabular}


Table (3):Correlation matrix of the scores of job involvement, job enrichment, commitment, and job satisfaction.

\begin{tabular}{|l|c|c|c|c|}
\hline \multirow{2}{*}{ Scores } & \multicolumn{4}{|c|}{ Pearson correlation coefficient } \\
\cline { 2 - 5 } & \multicolumn{3}{|c|}{ Scores } \\
\cline { 2 - 5 } & Commitment & Job satisfaction & Job enrichment & Job involvement \\
\hline Job Involvement & $0.678^{*} *$ & $0.664 * *$ & $0.480 * *$ & ----- \\
\hline Job Enrichment & $0.527 * *$ & $0.537 * *$ & ------ & $0.480 * *$ \\
\hline Commitment & ------ & $0.647 * *$ & $0.527 * *$ & $0.677^{* *}$ \\
\hline Job satisfaction & $0.647 * *$ & ------ & $0.537 * *$ & $0.664 * *$ \\
\hline
\end{tabular}

(**) Statistically significant at $(p<0.01)$

Table (4): Correlation between the scores of job involvement, job enrichment commitment, and job satisfaction and nurses' personal characteristics.

\begin{tabular}{|c|c|c|c|c|c|c|c|}
\hline \multirow{3}{*}{ Characteristics } & \multicolumn{7}{|c|}{ Spearman rank correlation coefficient } \\
\hline & \multicolumn{7}{|c|}{ Scores } \\
\hline & $\begin{array}{c}\text { Job } \\
\text { involvement }\end{array}$ & $\begin{array}{c}\text { Job } \\
\text { Enrichment }\end{array}$ & $\begin{array}{c}\text { Job } \\
\text { satisfaction }\end{array}$ & $\begin{array}{c}\text { Emotional } \\
\text { commitment }\end{array}$ & $\begin{array}{c}\text { Continence } \\
\text { commitment }\end{array}$ & $\begin{array}{c}\text { Natural } \\
\text { Commitment }\end{array}$ & $\begin{array}{c}\text { Total } \\
\text { commitmen }\end{array}$ \\
\hline $\mathrm{Age}^{\#}$ & $-0.176^{*}$ & -0.106 & $-0.347 * *$ & -0.028 & -0.082 & -0.074 & $0.056-$ \\
\hline Sex & 0.126 & 0.037 & 0.129 & -0.047 & -0.013 & -0.040 & 0.081 \\
\hline $\begin{array}{l}\text { Experience } \\
\text { years }\end{array}$ & -0.123 & $0.068-$ & $-0.211 * *$ & 0.021 & -0.061 & -0.048 & -0.022 \\
\hline
\end{tabular}

(\#) Pearson correlation coefficient

(*) Statistically significant at $p<0.05$

$(* *)$ statistically significant at $p<0.01$

Table ( 5): Best fitting multiple linear regression model for nurses' satisfaction scores.

\begin{tabular}{|l|c|c|c|c|c|}
\hline \multirow{2}{*}{} & \multicolumn{2}{|l|}{ Unstandardized Coefficients } & Standardized Coefficients & t-test & p-value \\
\cline { 2 - 6 } & $\mathbf{B}$ & Std. Error & & & \\
\hline Constant & 10.78 & 6.281 & & 1.718 & 0.087 \\
\hline Department & 4.378 & 1.502 & 0.121 & 2.915 & $0.004^{* *}$ \\
\hline Age & -12.098 & 1.932 & -0.649 & -6.260 & $0.000^{* *}$ \\
\hline Years of experience & 7.128 & 1.609 & 0.414 & 4.177 & $0.000^{* *}$ \\
\hline Involvement score & 0.219 & 0.039 & 0.301 & 5.573 & $0.000^{* *}$ \\
\hline Enrichment score & 0.191 & 0.046 & 0.201 & 4.154 & $0.010^{*}$ \\
\hline Commitment score & 0.266 & 0.123 & 0.177 & 2.622 & $0.009^{* *}$ \\
\hline
\end{tabular}

r-square $=0.729$

Model ANOVA: $F=57.69, p<0.001$

Variables excluded by model (not significant): Sex, qualification 


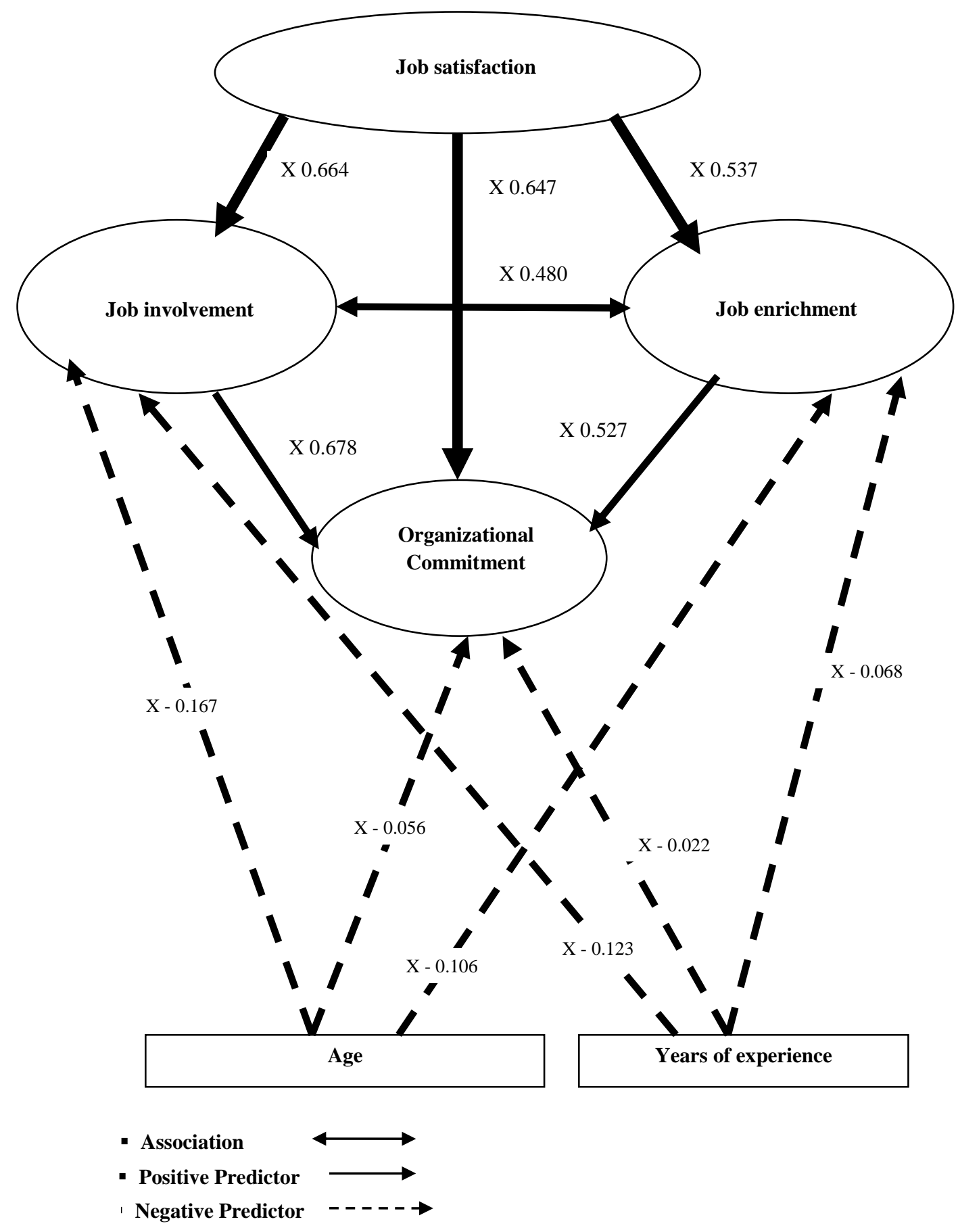

(Fig. 1) Proposed Model in this study 
The age of the studied nurses ranged between 18.and 38 years, with a mean 24.7 years (Table, 1). More than half of them were from medical department $(54.2 \%)$. More than two thirds were females (69.0\%), and the years of experience ranged between one to twenty years, with a mean of 10.1 years.

Table (2): Shows that $44.3 \%$ of the nurses had job involvement compared to more than three quarters of them had job enrichment $(75.4 \%)$. Continuous type of commitment was being more than natural and emotional commitment $(58.13 \%$; 55.67\%; and $31.03 \%$ ) respectively. On the other hand, the job satisfaction was low, $37.44 \%$.

Table (3): Shows the correlations among the scores of job involvement, job enrichment, job commitment, and satisfaction revealed that job satisfaction had strong positive statistically significant correlations with job involvement $(\mathrm{r}=0.664)$, job enrichment $(\mathrm{r}=0.537)$ and commitment $(\mathrm{r}=0.647)$.

Concerning the relations with nurses' personal characteristics,(Table,4): demonstrates that job enrichment had weak negative statistically significant correlations with age and years of experience

$(\mathrm{r}=-0.106 \& \mathrm{r}=-0.068)$ respectively. In addition, commitment had weak negative correlations with age and years of experience ( $\mathrm{r}=-0.056 \& \mathrm{r}=-0.022)$ respectively. Meanwhile, job satisfaction had weak negative statistically significant correlation with age and years of experience $(\mathrm{r}=-0.347 \&-0.211)$.

Multivariate analysis (Table, 5) demonstrated that the statistically significant independent predictors of the nurses' satisfaction scores were their scores of job involvement, job enrichment and commitment, as well as their department, age and years of experience. All the six had a positive effect on the score of job satisfaction except age had a negative effect. However, according to the value of r-square, the model explains $72.9 \%$ of the variation in the job satisfaction score. On the other hand, nurses' sex, and qualification had no significant effect on their organizational commitment score.

Fig.(1):Illustrates the correlations among the scores of job involvement, job enrichment, job commitment, and satisfaction which revealed that job satisfaction had strong positive statistically significant correlations with job involvement $(r=0.664)$, job enrichment $(\mathrm{r}=0.537)$ and commitment $(\mathrm{r}=0.647)$. Meanwhile, there were statistically significant independent predictors of the nurses' satisfaction scores were their scores of job involvement, job enrichment and organizational commitment. Job involvement, job enrichment and organizational commitment had a negative correlation with nurses' age $(r=-0.176 ; r=-0.106 ;$ and $r=-0.056)$ respectively; in-addition job enrichment and organizational commitment had a negative correlation with years of experience $(r=-0.068 ; \mathrm{r}=-$ 0.022 ) respectively. However, according to the value of r-square, the model explains $72.9 \%$ of the variation in the job satisfaction score.

\section{Discussion}

The job involvement of the individual seems to be potentially fundamental to the satisfaction of certain salient psychological needs that could lead to positive organizational implications. People with high levels of job involvement tend to be satisfied with their jobs and highly committed to their careers, professions, and employing organizations (Methta, 2011). As Mudrack , (2004) explains that a highly involved people thus tend not to give up easily, may feel almost a moral obligation to be involved with their jobs, and may tend to be set in their ways.

Ishwara \& Laxman, (2007) evaluated the perceived level of job involvement among the university teachers working at the postgraduate departments in Karnataka State. Analysis of the data indicated that around $60 \%$ of the university teachers perceived and were reported to have been moderately involved in the job.

The result of the present study showed that less than half of the study subjects had job involvement compared to three quarters had job enrichment and continuous type of commitment was being more than the other types of commitment and job satisfaction was low (Table, 2). These results might be attributed to the nurse managers should continually plan initiatives to keep nurses at all career stages committed through active involvement in their job. They need to be sensitive to nurses at all career stages in order to tailor jobs and responsibilities according to level of expertise and needs.

The present study showed that job satisfaction has a greater power to influence organizational commitment, job involvement and job enrichment; therefore the results tell us that organizations must pay more attention to promoting job satisfaction in order to ensure higher levels of organizational commitment. The results obtained from this study showed that there is a significant positive association between job involvement, job enrichment, organizational commitment and job satisfaction (Table, 3): The fact that job satisfaction was found to account for a higher proportion of variance in organizational commitment than job involvement means that organizations must pay more attention to promoting job satisfaction in order to ensure a higher level of organizational commitment. The main practical implication of this study relate to employee retention or prevention of a high rate of labor turnover. Organizational commitment is likely to be 
strongly associated with employee retention. To ensure organizational commitment, health organization must promote job involvement, job enrichment and job satisfaction. This is likely to lead to employee retention. The fact that job satisfactions were found to be highly inter-correlated means that they are all equally important as probable determinants of organizational commitment. Organizations must, therefore, constantly upgrade job satisfaction despite the different working environments.

Results of the present study illustrated that job satisfaction had a strong positive statistically significant correlations with job involvement, enrichment, and commitment (Table, 3). These results might be attributed to nurses may be committed to their organization because they choose nursing as a profession; the particular hospital they are employed in may not mean as much as the profession itself. Clearly, involvement in work or job was related to commitment to, and identification with, the employing organization, but not to satisfaction. The findings also suggest that involvement does not necessarily lead to satisfaction that's because the work may be perceived as repetitive and routine, lacking in variety or significance. The nature of the work may still demand involvement but may not lead to satisfaction. It was inconsistent with Patel, (1995) in India, who found that almost all studied nurses have exhibited job involvement and job satisfaction, but no significant positive correlation was found between job satisfaction and job involvement, enrichment and commitment.

The current study findings revealed that job involvement had a strong positive and significant relationship with organizational commitment. Although the relationship between job involvement and employees job satisfaction was also positive. Similarly, job satisfaction was revealed to have a positive and significant relationship with job enrichment and organizational commitment. Finally, organizational commitment was revealed to have a positive and significant relationship with job involvement and enrichment. Based on the findings above, it was concluded that as an employee develops a favorable attitude toward one aspect of the job based on unique experiences (e.g job involvement, job enrichment), such an employee is also likely to react favorably to other related aspects of the job (e.g job satisfaction, organizational commitment). Thus, employees who are involved in their job, for example, are likely to be satisfied with the job, become committed to their organization. Similarly, employees who are dissatisfied with their job may become less involved in the work, less committed to their employer and organization. Job enrichment can also be used as a motivational strategy to satisfy these employees through providing opportunities for personal achievement, challenge and recognitions (Fig. 1).

In the same line, the findings were supported by a study done by Emami (2012), who investigated the relationship between job satisfaction, job involvement, and organizational commitment among lower-level employees and indicated that though both job satisfaction and job involvement are strongly associated with organizational commitment, job satisfaction accounts for a higher proportion of variance in organizational commitment than job involvement. Job satisfaction was found to be significantly and highly inter-correlated, an indication that it is an equally associated with organizational commitment.

Meanwhile, inconsistent with the present study findings Moynihan \& Pandey (2007) made a comparison of job satisfaction, job involvement and organizational commitment using a sample of public sector health and human services managers. The results showed that managers had the greatest influence over job satisfaction and the least influence over job involvement. In addition, Ha-Young \& Hyun (2009) conducted a study with the prime aim to analyze an empirical test to classify workers' character in private and public organizations. He sought to answer the question, "what are important organizational determinants of job involvement and job satisfaction?" his study findings suggested that job satisfaction has greater power to influence organizational commitment than job involvement. The results also suggested that, the higher the degree of job involvement, the greater the organizational commitment and effectiveness. They further argued that an increase in the work related attitudes and wage satisfaction results in an increase in organizational commitment. These differing results may be due to the differences in culture.

\section{Conclusions}

In the light of the study results, the following conclusions can be drawn:

- The correlations among the scores of job involvement, job enrichment, job commitment, and satisfaction revealed that job satisfaction had strong positive statistically significant correlations with job involvement $(\mathrm{r}=0.664)$, job enrichment $(\mathrm{r}=0.537)$ and commitment $(\mathrm{r}=0.647)$.

- Concerning the relations of job involvement, job enrichment, job commitment, and satisfaction with nurses' characteristics, job enrichment had weak negative statistically significant correlations with age and years of experience $(r=-0.106 \& r=-0.068)$ 
respectively. In addition, commitment had weak negative correlations with age and years of experience $(r=-0.056 \& r=-0.022)$ respectively. Meanwhile, job satisfaction had weak negative statistically significant correlation with age and years of experience ( $r=-0.347 \&-0.211)$.

- Design a model that shows a positive association among job involvement, job enrichment, organizational commitment, and job satisfaction. In addition, Job involvement, job enrichment and organizational commitment had a negative correlation with nurses' age. Moreover, job enrichment and organizational commitment had a negative correlation with years of experience.

\section{Recommendations}

In the light of the findings, the researcher recommended that:

- Replication of the study should be done to test the proposed model designed in the present study at different health care settings.

- Managers can also use job enrichment, the practice of giving employees a high degree of control over their work, from planning and organization, through implementing the required activities and evaluating the results.

- This study provides a theoretical and empirical basis for further study of nursing issues including work values, job involvement, and organizational commitment.

\section{References}

1. Balay, R., (2000): Organizational commitment. Ankara: Nobel Media Dagitim.

2. Can, H., Akgun, A., \& Kavuncubasi, S., (2001): Human Resources Management, Siyasal Kitabevi, Ankara, .

3. Carmeli, A., (2005): Perceived external prestige, affective commitment, and citizenship behaviors. Organizational Studies, 26 (3), Pp. 443-464.

4. Cook, J., \& Wall, T., (1980): New work attitude measures of trust, organizational commitment and personal need non-fulfillment . Journal of occupational Psychology, 53: Pp. 3952.

5. Emami, M., (2012): The Relationship between Job Involvement, Job Satisfaction and Organizational Commitment among lower-level Employees, Asian Journal of Social and Economic Sciences, 1(1): 23-33.

6. Hackett, R., Lapierre, L., \& Hausdorf, P., (2001): Understanding the links between work commitments constructs. Journal of Vocational Behavior, 58: Pp. 392-413.

7. Ha-Young, H., (2009): Analysis the factors impact on the Job Involvement and
Organizational commitment. Department of Public Administration Korea University

8. Ishwara, P., \& Laxman, P., (2007): .Job involvement among university teachers: A Case Study of Karnataka State. The Icfai Journal of Higher Education, Vol. 2, No. 3, Pp.59-65.

9. Kanungo, R., (1982):Measurement of job and work involvement. Journal of Applied Psychology, 67:Pp. 341-349.

10. Leach, D., \& Wall, T., (2004): What is? Job design. Retrieved February 10, 2004 from: http://www.shef.ac.uk/ iwp/publications/whatis/j ob_design.pdf.

11. Methta, S., (2011): Job involvement among working women, International Journal of Multidisciplinary Research Vol.1 Issue 2, Pp.11

12. Moynihan, D., \& Pandey, S., (2007): Finding workable levers over work motivation: Comparing job satisfaction, job involvement and organizational commitment. Administration \& Society, 39 (7): 803-832.

13. Mudrack, P., (2004): Job involvement, obsessive-compulsive personality traits, and workaholic behavioral tendencies. Journal of Organizational Change Management, 17, Pp.490-508.

14. Narimawati, S., (2007): The Influence of Work Satisfaction, Organizational Commitment and Turnover Intention Towards the Performance of Lecturers at West Java's Private Higher Education Institution', Journal of Applied Sciences Research, vol. 3, no. 7, pp. 549-557.

15. Patel, M., (1995): job satisfaction and job involvement among nurses, Journal of the Indian Academy of Applied Psychology., Jul; 21(2): Pp.119-25.

16. Robbins ,S (2005): Essentials of Organizational Behavior. New Jersey: Pearson.

17. Sahnawaz, M., \& Juyal R., (2006): Human Resources Management Practices and Organizational Commitment in Different Organizations. J. Indian Acad. Appl. Psychol. 32: Pp.171-178.

18. Samad, S., (2007): Assessing the Effects of Job Satisfaction and Psychological Contract on Organizational Commitment among Employees in Malaysian SMEs. The 4th SMEs IN A Global Economy Conference 2007.

19. Seashore, S., Lawler, E., Mirvis P., \& Cammann C., (1982): Observing and measuring organization change: A guide to field practice. New York: Wiley.

20. Tomey, A., (2000): Guide to nursing management and leadership (6th ed.). St. Louis: Mosby. 
